\title{
IDENTIFIKASI FAKTOR-FAKTOR PENYEBAB \\ KEENGGANAN MASYARAKAT BERURUSAN DENGAN PAJAK (STUDI EKSPLORASI MASYARAKAT DI KOTA PALEMBANG)
}

\author{
Antonius Singgih Setiawan \\ STIE Musi Palembang \\ e-mail : assetiawan1208@gmail.com
}

\begin{abstract}
This study aims to identify people reluctance factors in dealing with taxes. Using a sample of 850 respondents and analyzed using descriptive statistical methods can be gathered that the peoples of the city of Palembang has a tendency reluctant in dealing with taxes, many factors identified to be the cause (1) The level of corruption of government officials/taxes are still high (2) Facilities provided by the government are not satisfactory (3) Lack of transparency in tax matters (4) Feeling not benefit from the tax (5) Tax rules are complex and changing, and(6) They do not understand the rules of taxation in Indonesia.
\end{abstract}

Keywords: Reluctance, Reluctance Factors, Tax

\begin{abstract}
PENDAHULUAN
Widayati dan Nurlis (2010) manyatakan bahwa saat ini pajak menjadi sumber terbesar penerimaan negara. Setidaknya dua pertiga penerimaan negara Indonesia bersumber dari pajak. Pendapat yang sama juga diungkapkan oleh Rustiyaningsih (2011) yang menyatakan bahwa pajak merupakan salah satu sumber penerimaan negara yang penting selain sumber penerimaan lainnya. Untuk mencapai tujuan tersebut, maka negara melalui pemerintah harus berupaya secara optimal menggali semua potensi sehubungan dengan pemungutan pajak. Wujud dari upaya tersebut, pemerintah telah berupaya untuk mereformasi sistem dan kelembagaan perpajakan Indonesia.Hal itu seperti juga diungkapkan oleh Eupharasia (2010) yang menyatakan bahwa sasaran utama kebijakan keuangan negara di bidang penerimaan negara adalah menggali, mendorong dan mengembangkan sumber-sumber
\end{abstract}

penerimaan dari dalam negeri, yang berkaitan dengan sektor perpajakan karena keberhasilan dari sektor ini akan berdampak positif dalam mengembangkan sektor perekonomian dan dunia usaha.

Pancawati dan Nila (2011) mengungkapkan bahwa dominasi pajak sebagai sumber penerimaan negara merupakan suatu kewajaran. Hal tersebut dikarenakan sumber penerimaan dari pajak memiliki umur yang tidak terbatas. Selain itu, pajak merupakan suatu kewajiban yang memiliki unsur memaksa terhadap setiap warga negara yang telah memenuhi persyaratan untuk dikenakan kewajiban pajak. Namun ditambahkan oleh Pancawati dan Nila (2011) bahwa pemungutan pajak bukanlah hal yang mudah. Hal ini dapat dilihat dari tingkat kepatuhan dan kesadaran para wajib pajak dalam menjalankan aturan perpajakan yang berlaku.

Dukungan pendapat juga disampaikan oleh Rustiyaningsih (2011) yang menyatakan 
bahwa usaha untuk meningkatkan penerimaan dari sektor pajak masih menemukan banyak kendala. Kendala-kendala tersebut antara lain berhubungan dengan tingkat kesadaran wajib pajak yang masih rendah. Di sisi lain wajib pajak korporasi (perusahaan) sering kali memainkan angka-angka laporan keuangan perusahaannya untuk melakukan pengurangan beban pajak yang harus dibayarkan ke negara. Hal ini seperti diungkapkan oleh Krisnata dan Supramono (2012) yang menyatakan bahwa bagi perusahaan, pajak dianggap sebagai beban yang akan mengurangi keuntungan perusahaan, sehingga menyebabkan perusahaan akan mencari cara untuk mengurangi biaya pajak.

Fakta belum tingginya kesadaran wajib pajak dalam menjalankan kewajiban perpajakan sering dapat dilihat dari berbagai informasi yang dikeluarkan oleh pihak yang berwenang. Antara lain adalah pernyataan Agus Martowardojo yang dikutip Manurung (2013) menyebutkan bahwa untuk tahun 2012 orang pribadi yang seharusnya membayar pajak atau yang mempunyai penghasilan diatas Penghasilan Tidak Kena Pajak (PTKP) sebanyak 60 juta orang, tetapi jumlah yang mendaftarkan dirinya sebagai wajib pajak hanya 20 juta orang dan yang membayar pajaknya/ melapor Surat Pemberitahuan (SPT) Pajak Penghasilannya hanya 8,8 juta orang dengan rasio SPT sekitar 14,7 persen.Sementara badan usaha yang terdaftar sebanyak 5 juta, yang mau mendaftarkan dirinya sebagai wajib pajak hanya 1,9 juta dan yang membayar pajak/melapor Surat Pemberitahuan (SPT) Pajak Penghasilannya hanya 520 ribu badan usaha dengan rasio SPT sekitar 10,4 persen.

Fakta lain diungkapkan oleh Direktur Jenderal Pajak Kementerian Keuangan Fuad Rahmany yang dikutip media online beritasore. com/2013/09/23, yang menyatakan bahwa Penerimaan pajak bisa mencapai kisaran Rp2.000 triliun apabila seluruh Wajib Pajak memiliki kesadaran untuk memenuhi kewajiban perpajakan sesuai ketentuan .Penerimaan pajak tahun 2013 sekitar Rp1.148 triliun atau baru 57,4\%. Masih ada sekitar 40 juta Wajib Pajak Orang Pribadi dan lima juta Wajib Pajak Badan yang belum membayar pajak kepada negara. Jumlah tersebut lebih banyak dibandingkan Wajib Pajak yang telah memenuhi kewajibannya.

Kondisi kepatuhan wajib pajak ini semakin memprihatinkan karena ternyata untuk periode 2013 target penerimaan pajak juga tidak tercapai. Hal ini seperti di kutip dari berita bisnis. liputan6.com yang menyatakan kekhawatiran tak tercapainya target penerimaan pajak pada 2013 akhirnya menjadi kenyataan. Hal tersebut ditunjukan oleh data hingga 31 Desember 2013 menunjukan penerimaan negara yang bersumber dari pajak kurang $\mathrm{Rp} 76,3$ triliun dari target pemerintah. Dan seperti dikutip dari voaindonesia.com, BPK mengatakan pemerintah gagal mencapai target yang ditetapkan sejak 2009 hingga 2012.

Beberapa peneliti telah melakukan studi dalam konteks hubungan kausalitas antara beberapa faktor yang diduga memengaruhi kepatuhan wajib pajak terhadap kegiatan perpajakkannya. Penelitian tersebut antara lain dilakukan oleh Yenni dan Arja (2013) yang menyimpulkan motivational posture berupa commitment, capitulation, resistance dan disengagement tidak mempengaruhi kepatuhan wajib pajak, sementara game playing mampu mempengaruhi kepatuhan wajib pajak orang pribadi.

Krisnata dan Supramono (2012) menyimpulkan bahwa levarage perusahaan manufaktur berpengaruh positif terhadap agresifitas pajak perusahaan, demikian pula komisaris independen, namun likuiditas perusahaan tidak memiliki pengaruh terhadap agresifitas pajak perusahaan. Mienati dan Heru (2011) menyimpulkan bahwa moral etika pajak berpengaruh terhadapintensitas wajib pajak untuk menghindar pajak. Erwin (2009) menemukan 
kesimpulan bahwa persepsi kontrol perilaku tidak berpengaruh langsung terhadap kepatuhan pajak, semakin tinggi persepsi tax professional atas kontrol perilaku akan mendorong kepatuhan kewajiban pajak begitupun dengan kondisi keuangan, kondisi fasilitas perusahaan serta kondisi iklim organisasi berpengaruh terhadap kepatuhan pajak.

Penelitian Pancawati dan Nila (2011) menunjukkan kesimpulan bahwa kesadaran dan kualitas layanan berpengaruh terhadap kemauan membayar pajak, sementara pengetahuan peraturan, pemahaman peraturan serta persepsi efektifitas sistem perpajakan tidak berpengaruh terhadap kemauan membayar pajak. Widayati dan Nurlis (2010) menemukan kesimpulan bahwa faktor kesadaran, dan persepsi efektifitas sistem perpajakan tidak berpengaruh terhadap kemauan wajib pajak membayar pajak, sementara faktor pengetahuan dan pemahaman peraturan perpajakan berpengaruh terhadap kemauan membayar pajak. Hasil lainnya ditunjukkan oleh penelitian Yulianto (2009) yang menyimpulkan bahwa implementasi kebijakan self assesment system berpengaruh pada ketaatan wajib pajak orang pribadi. Sementara hasil penelitian Hutagaol et al (2007) menyebutkan bahwa kepatuhan wajib pajak dipengaruhi oleh besarnya penghasilan, sanksi pajak, persepsi penggunaan uang pajak secara transparan dan akuntabilitas, perlakuan pajak yang adil dan penegakan hukum.

Beberapa informasi yang telah diuraikan di atas menunjukan adanya kontradiksi antara harapan akan penerimaan dari sektor pajak dengan penerimaan aktual pajak. Begitupun dengan beberapa hasil penelitian di atas juga menunjukan fakta beragam tentang penyebab ketaatan wajib pajak dalam melaksanakan kewajiban pajak. Jika dilihat dari fakta aktual mengenai kewajiban formal wajib pajak, kondisi ideal yang diharapkan tentang ketaatan wajib pajak sertaserta kajian mengenai ketaatan wajib pajak selalu menarik untuk diteliti. Beberapa hasil penelitian di atas nampak masih menunjukkan model penelitian kausalitas yang seringkali belum mendasarkan pada preferensi aktual mengenai mengapa wajib pajak tidak taat atau taat terhadap kewajiban pajak. Karena model penelitian yang dipakai seringkali masih mengarah pada situasi normatif sehingga kurang dapat menggali informasi lebih dalam tentang ketaatan dan penyebab ketaatan itu terjadi.

Oleh karena itu, penelitian ini akan menjadi berbeda dengan penelitan-penelitian sebelumnya. Penelitian ini akan lebih fokus mengidentifikasi kejujuran dari para wajib pajak yang akan dijadikan reponden untuk menentukan preferensi mereka dalam memastikan, apakah mereka memang menjadi pihak yang merasa enggan berurusan dengan pajak, dan mereka diminta untuk ununjukkan preferensi mereka dalam menentukan faktor apa saja yang sering kali menjadi penyebab wajib pajak enggan berurusan dengan pajak. Berdasarkan perbedaan dari penelitian ini, maka tujuan yang hendak di capai dari penelitian ini adalah mendapatkan jawaban apakah memang ada kecenderungan wajib pajak enggan berurusan dengan pajak dan faktor-faktor apa saja yang diyakini dapat menjadi penyebab keengganan tersebut.

\section{REVIEW LITERATUR DAN HIPOTESIS}

\section{Kepatuhan Wajib Pajak}

Kepatuhan wajib pajak tercermin dari seberapa tinggi wajib pajak mempunyai keinginan untuk membayar dan melaporkan pajaknya. Hal ini seperti di uraiakan oleh Rustyaningsih (2011) yang menyatakan kepatuhan wajib pajak diklasifikasikan kedalam dua kategori, (1) kepatuhan formal, yaitu suatu keadaan dimana wajib pajak memenuhi kewajiban formal sesuai dengan ketentuan perundang-undangan pajak, dan (2) kepatuhan material, yaitu dimana wajib pajak memenuhi ketentuan material peraturan perpajakan. Vanessa dan Hari (2009) mengaitkan 
kepatuhan pajak dengan kemauan membayar pajak. Dalam hal itu, kemauan membayar pajak diartikan sebagai suatu nilai yang rela didistribusikan oleh seseorang berdasarkan suatu peraturan untuk pembiayaan umum negara tanpa jasa imbal secara langsung. Berdasarkan uraian tersebut, maka dapat disimpulkan jika seseorang enggan berurusan dengan pajak maka orang tersebut tidak patuh terhadap kewajiban pajaknya.

\section{Identifikasi Faktor Keengganan Wajib Pajak Berurusan Dengan Pajak}

Widayati dan Nurlis (2010) menyatakan bahwa kesadaran merupakan unsur yang dimiliki manusia dalam memahami realitas dan bagaimana cara bertindak atau menyikapi realitas. Kesadaran yang dimiliki manusia terdiri dari kesadaran dalam diri, kesadaran akan sesama, masa silam dan kemungkinan masa depan. Keangganan wajib pajak berurusan dengan pajak bisa mencerminkan kesadaran mereka dalam menyikapi permasalahan pajaknya. Dari konteks tersebut dapat diartikan bahwa ketidak sadaran yang berdampak pada keenganan berurusan dengan pajak, menunjukkan sikap ketidak patuhan wajib pajak pada peraturan perpajakan.

Manurung (2013) mengidentifikasi beberapa hal yang dimungkinkan menjadi pemicu keengganan masyarakat berpartisipasi dalam masalah perpajakan. Terdapat dua hal mendasar mengapa keengganan terjadi, (1) ketidakpuasan masyarakat terhadap pelayanan publik, pembangunan infrastruktur yang tidak merata, dan banyaknya kasus korupsi yang dilakukan pejabat tinggi, dan (2) masyarakat kurang merasakan manfaat dari pajak yang telah dibayar, misalnya masih banyaknya jalan yang rusak. Hal ini juga dikuatkan dari beberapa hasil penelitian yang tekah diuraikan pada bagian sebelumnya, bahwa ada banyak persoalan yang bisa berdampak pada kepatuhan wajib pajak dalam menjalankan kewajiban perpajakannya.

\section{METODE PENELITIAN}

Penelitian ini merupakan penelitian eksplorasi. Penelitian menggunakan teknik survei, dimana data yang dikumpulkan merupakan data sebaran demografi responden dan data jawaban atas masalah yang akan diidentifikasi. Survei dilakukan terhadap masyarakat umum di kota Palembang, lokasi survei dilakukan di pusatpusat keramaian seperti pusat perbelanjaan, pusat rekreasi keluarga, dan fasilitas umum lainnya. Hal ini dilakukan untuk memudahkan mendapatkan responden dengan karateristik seheterogen mungkin.Data sehubungan dengan permasalahan yang akan diteliti terdiri dari tujuh pernyataan mendasar yang diidentifikasi berdasarkan literatur dan hasil-hasil penelitian sebelumnya, yaitu: (1) Keengganan berurusan dengan pajak, (2) Tidak/belum pahamnya mereka terhadap aturan perpajakan di Indonesia, (3). Aturan pajak yang rumit dan berganti-ganti (4) Kurangnya transparansi dalam urusan pajak (5) Fasilitas yang diberikan pemerintah belum memuaskan (6) Tingkat korupsi aparatur pemerintah/pajak masih tinggi (7) Merasa tidak memperoleh manfaat dari pajak.

Berdasarkan pernyataan tersebut, responden diminta untuk menentukan tingkat kesetujuan mereka. Selain dari tujuh hal tersebut, data lain yang dikumpulkan adalah data gender, usia, profesi dan kepemilikan NPWP. Data yang diperoleh diolah mengunakan statistik deskriptif, untuk mengetahui karateristik demografi responden dan memberikan simpulan atas masalah yang diteliti.

\section{HASIL PENELITIAN DAN PEMBAHASAN}

Berdasarkan data survei (bisa dilihat pada lampiran) yang dilakukan pada periode tanggal 2 - 10 November 2013, menunjukan 850 orang responden berpartisipasi dalam penelitian 
ini. Dari 850 0rang responden, 495 orang $(58,2 \%)$ adalah pria, sementara 355 orang $(41,8 \%)$ adalah wanita. Data ini menunjukkan terdapat situasi yang menarik, bahwa jumlah pria yang berpartisipasi lebih banyak dari yang wanita. Hal ini menunjukkan bahwa dominasi pria dalam pengambilan keputusan di wilayah Indonesia khususnya kota Palembang masih lebih dominan dari pada wanita.

Usia responden yang berpartisipasi dalam penelitian ini berkisar antara 17 hingga 82 tahun dengan rata-rata usia 32,99 tahun. Data ini juga menarik untuk dilihat karena dengan rata-rata usia 32,99 tahun menunjukkan bahwa rata-rata responden yang berpartisipasi dalam penelitian ini adalah responden dalam masa usia produktif, sehingga mereka dapat berperan lebih besar dalam melaksanakan kewajiban perpajakannya, menginggat pada usia produktif mereka berpenghasilan.

Untuk profesi responden, profesi karyawan (58 \%) memiliki jumlah partisipasi yang lebih besar dibandingan profesi pengusaha $(23,1 \%)$ dan profesi profesional $(18,9 \%)$. Hal ini menunjukkan bahwa masyarakat di kota Palembang lebih banyak memilih menjadi karyawan dari pada menjadi pengusaha dan profesional.

Untuk demografi kepemilikan NPWP, berdasarkan data yang terkumpul menunjukkan hampir setengah dari warga kota Palembang sudah memiliki NPWP, ditunjukkan pada data 49,5\% responden telah memiliki NPWP sementara $50,5 \%$ responden belum memiliki. Walaupun belum lebih setengah dari warga produktif di kota Palembang memiliki NPWP, namun situasi ini sebenarnya dapat menunjukkan bahwa sudah banyak warga produktif di kota Palembang yang telah bersinggungan dengan Pajak khususnya Pajak Penghasilan.
Tabel. 1

Keengganan dan Faktor Keengganan Berurusan dengan Pajak

\begin{tabular}{lccc}
\hline \multicolumn{1}{c}{ Identifikasi (Faktor) } & $\begin{array}{c}\text { Sangat } \\
\text { Setuju } \\
\text { Setuju }\end{array}$ & $\begin{array}{c}\text { Ragu- } \\
\text { ragu }\end{array}$ & $\begin{array}{c}\text { Tidak Setuju }+ \\
\text { Sangat Tidak } \\
\text { Setuju }\end{array}$ \\
\hline $\begin{array}{l}\text { Keengganan berurusan } \\
\text { dengan pajak }\end{array}$ & $50,4 \%$ & $23,5 \%$ & $26,2 \%$ \\
$\begin{array}{l}\text { Tingkat korupsi aparatur } \\
\text { pemerintah/pajak masih } \\
\text { tinggi }\end{array}$ & $86,7 \%$ & $10,7 \%$ & $2,6 \%$ \\
$\begin{array}{l}\text { Fasilitas dari pemerintah } \\
\text { belum memuaskan }\end{array}$ & $72,5 \%$ & $19,4 \%$ & $8,1 \%$ \\
$\begin{array}{l}\text { Kurang transparansi } \\
\text { urusan pajak }\end{array}$ & $61,5 \%$ & $37,5 \%$ & $13,1 \%$ \\
$\begin{array}{l}\text { Merasa tidak } \\
\text { memperoleh manfaat dari } \\
\text { pajak }\end{array}$ & $58,2 \%$ & $28 \%$ & $13,9 \%$ \\
$\begin{array}{l}\text { Aturan pajak rumit \& } \\
\text { berganti-ganti } \\
\text { Tidak/belum paham } \\
\text { aturan pajak }\end{array}$ & $52,4 \%$ & $30,5 \%$ & $17,2 \%$ \\
\hline
\end{tabular}

Sumber: hasil olah data

Tabel. 1 menunjukkan rekapitulasi sehubungan dengan data indentifikasi masalah yang menjadi tujuan dari penelitian ini. Identifikasi mengenai tingkat kecenderungan wajib pajak di kota Palembang enggan berurusan dengan pajak menunjukkan angka 50,4 \% menyatakan setuju dan sangat setuju, sementara yang menyatakan sangat tidak setuju dan setuju hanya $26,2 \%$, sedangkan yang ragu-ragu $23,5 \%$. Fenomena ini menunjukkan bahwa masih banyak warga produktif di kota Palembang yang masih enggan berurusan dengan pajak. Situasi ini menarik jika dihubungkan dengan data kepemilikan NPWP. Secara pengamatan dapat dilihat ada kemungkinan hubungan jumlah masyarakat yang belum memiliki NPWP (50,5\%) dengan keengganan mereka berurusan dengan pajak.

Situasi yang teridentifikasi dari data keengganan masyarakat kota Palembang dalam berurusan dengn pajak nampaknya mampu mengkonfirmasi informasi tentang seringnya pemerintah tidak mampu mencapai target dalam 
menggumpulkan pendapatan negara dari sektor pajak. Hal ini semakin memprihatinkan, bahwa sesungguhnya masyarakat produktif di kota palembang terbagi dalam dua kelompok besar, yaitu kelompok karyawan (58\%) dan kelompok pengusaha dan profesional (42\%). Akan menjadi hal yang mengkhawatirkan jika pihak yang lebih memiliki keengganan tersebut adalah dari kelompok pengusaha dan profesional, menginggat sistem pajak di Indonesia lebih mengunakan self assesment system. Sementara untuk karyawan urusan pajak lebih banyak ditangani oleh pihak ketiga atau withholding system.

Dari enam faktor yang diidentifikasi sebagai faktor yang mungkin menjadi penyebab masyarakat enggan berurusan dengan pajak dalam penelitaian ini, semua faktor mendapatkan nilai tertinggi untuk jawaban setuju dan sangat setuju dari responden. Hampir semua faktor mendapatkan nilai kecil pada pilihan jawaban tidak setuju dan sangat tidak setuju. Jika diurutkan berdasarkan nilai kesetujuan, maka faktor tingkat korupsi aparatur penerintah /pajak yang masih tinggi menjadi faktor yang paling tinggi menyebabkan keenggganan masyarakat berurusan dengan pajak (86,7\%). Hal ini sangat jelas, dimana dalam beberapa tahun terakhir ini, banyak sekali terungkap kasus-kasus korupsi dengan nilai yang sangat besar, dan diantaranya adalah korupsi yang dilakukan oleh aparat pajak. Hal itu tentunya semakin membuat masyarakat tidak percaya dengan pajak, karena uang yang mereka bayarkan justru digunakan dengan tidak semestinya, sementara beban mereka tetap harus mereka bayar.

Faktor kedua yang dianggap menjadi faktor yang tinggi adalah Fasilitas dari pemerintah yang masih belum memuaskan (72,5\%). Hal ini menunjukkan belum meratanya pembangunan yang dirasakan oleh masyarakat.fasilitas-fasilitas umum yang belum memadai, khususnya sarana jalan dan transportasi, sarana pendidikan dan sarana kesehatan. Ketiga hal tersebut tentunya menjadi kebutuhan mendasar bagi masyarakat karena ketiga hal tersebut yang paling mudah dilihat dan dipersepsikan masyarakat. Saat ketiga hal tersebut belum memuaskan, maka dapat dipersepsikan uang pajak yang mereka bayarkan tidak teralokasikan denga semestinya, dan hal ini mengakibatkan mereka enggan berurusan dengan pajak.

Faktor ketiga adalah kurang trasparansinya urusan pajak $(61,5 \%)$. Persepsi ini muncul dimungkinkan karena masyarakat memandang kantor pajak dan aparatur pajak adalah fungsi yang ekslusif. Dalam kondisi seperti itu masyarakat masih belum merasa nyaman jika harus berurusan dengan pajak. Masih munculnya kesan mencari-cari kesalahan dalam proses pemeriksaan pajak yang dilakukan oleh petugas pajak dapat dipersepsikan sebagai tidakan kurangnya transparansi dalam proses pemeriksaan terhadap wajib pajak. Sehingga memungkinkan wajib pajak menjadi tidak mengerti mana yang benar dan mana yang salah. Dan hal tersebut dapat memicu keengganan masyarakat berurusan dengan pajak.

Faktor keempat adalah merasa tidak memperoleh manfaat dari pajak (58,2\%). Banyak masyarakat apatis terhadap pajak dikarenakan mereka merasa tidak dapat hidup secara sejahtera. Atau bahkan mereka merasa bahwa kondisi yang saat ini mereka alami karena berasal dari usaha mereka sendiri. Mereka tidak meresakan fungsi negara dalam kehidupan mereka. Walapupun hal ini sangat bersifat subjektif, tetapi faktor ini cukup beralasan menyebabkan keengan masyarakat berurusan dengan pajak.

Faktor kelima adalah aturan pajak rumit dan berganti-ganti (52,4\%). Bagi masyarakat awam kebanyakan memiliki kesulitan tersendiri jika harus membaca aturan hukum yang rumit. Tidak terkecuali untuk membaca dan memahami bahasa hukum aturan perpajakan. Kelemahan dari bahasa hukum adalah lebih perfokus pada filsafat teoritis dan bukan nya 
menggunakan bahasa-bahasa praktit. Hal ini menyebabkan kurang berminatnya masyarakat untuk mencoba membaca dan memahaminya. Kondisi ini diperberat dengan seringnya berganti aturan-aturan dalam perpajakan. Situasi ini dapat menyebabkan masyarakat menjadi apatis sehingga berdampak pada menjadi enggan berurusan dengan pajak.

Faktor terakhir adalah faktor tidak/belum paham dengan aturan pajak (48,6\%). Walaupun angka jawaban sangat setuju dan setuju tidak lebih dari 50\%, namun perlu dicatat bahwa 25,5\% responden menyatakan ragu-ragu. Berdasarkan fakta ini, dapat dimungkinkan masyarakat masih bingung untuk mengatakan bahwa mereka sudah paham atau memang belum paham. Kalau dikaitkan dengan faktor aturan yang berubahubah, faktor ini nampaknya juga memberikan kotribusi dalam keengganan masyarakat dalam berurusan dengan pajak.

\section{KESIMPULAN DAN SARAN}

Berdasarkan analisis data penelitian serta pembahasan hasil yang telah diuraikan bagian sebelumnya, maka dapat simpulkan bahwa masyarakat di kota Palembang teridentifikasi masih banyak yang cenderung enggan berusan dengan pajak. Hal ini dibuktikan dengan masih banyak masyarakat yang belum memiliki NPWP. Faktor alasan yang dapat diidentifikasi sebagai penyebab keengganan tersebut adalah(1) Tingkat korupsi aparatur pemerintah/pajak masih tinggi (2) Fasilitas yang diberikan pemerintah belum memuaskan (3) Kurangnya transparansi dalam urusan pajak (4) Merasa tidak memperoleh manfaat dari pajak (5) Aturan pajak yang rumit dan berganti-ganti dan (6)Tidak/belum pahamnya mereka terhadap aturan perpajakan di Indonesia.

Penelitian ini tentunya memiliki keterbatasan, antara lain faktor yang diidentifikafi terbatas pada enam faktor saja. Sementara lingkup penelitian hanya terbatas di kota
Palembang, sehingga tidak dapat digeneralisasi untuk wilayak lainnya. Sebagai saran untuk penelitian mendatang, penelitian ini dapat dijadikan landasan pengembangan penelitan sejenis khususnya di kota Palembang. Mengingat kota Palembang adalah kota multi etnis dan dengan tingkat pendidikan yang bervariatif, maka penelitian selanjutnya bisa melihat dua hal tersebut untuk diidentifikasi lebih lanjut.Saran bagi lembaga perpajakan di Indonesia, perlu adanya peningkatan edukasi bagi masyarakat akan pentingnya pajak, dan lebih berkomitmen untuk mensukseskan reformasi perpajakan sesuai dengan apa yang telah dicanangkan, hal ini perlu dilakukan untuk mengatasi rendahnya kesadaran masyarakat akan masalah perpajakan.

\section{DAFTAR PUSTAKA}

Erwin. H, 2009, "Perilaku Kepatuhan Wajib Pajak Badan” Bisnis \& Birokrasi, Jurnal Ilmu Administrasi dan Organisasi, Vol. 16 No. 296 - 104

Euphrasia. S S, 2010, “ Pengarut Tingkat Kepatuhan Kewajiban Pajak Badan Terhadap Peningkatan Penerimaan Pajak Penghasilan Badan:, Jurnal Ekonomi Bisnis, Vo;. 5 No. $155-65$

J. Hutagaol, Wing WW, Arya P, 2007, "Strategi Meningkatkan Kepatuhan Wajib Pajak", Akuntabilitas, Vol.6 N0.2 168 - 193

Mienati. S L, Heru. T, 2011, “Pengaruh Moderasi Sosio Demografi terhadap Hubungan Antara Moral-Etika Pajak dan Tax Avoidance Pajak Penghasilan Wajib Pajak Badan di KPP Surabaya", Majalah Ekonomi Tahun XXI No. 2185 - 197

Krisnata. D. S, Supramon, 2012, "Likuiditas, Laverage, Komisaris Independen dan Manajemen Laba terhadap Agretivitas Pajak Perusahaan", Jurnal Keuangan dan Perbankan, Vol. 16 No. 2167 - 177 
Pancawati Hardiningsih, 2011, "Faktorfaktor yang Mempengaruhi Kemauan Membayar Pajak", Dinamika Keuangan dan Perbankan Vol.3 No.1 126 - 142

Sri Rustiyaningsih, 2011, "Faktor-faktor yang Mempengaruhi Kepatuhan Wajib Pajak" Widya Warta, No. 2 Th XXXV, $44-54$

Surya Manurung, 2013 “Kompleksitas Kepatuhan Pajakhttp://www.pajak.go.id/content/ article/kompleksitas-kepatuhan-pajak

Widayati, Nurlis, 2010, "Faktor-Faktor yang Mempengaruhi Kemauan Untuk Membayar Pajak Wajib Pajak Orang Pribadi Yang Melakukan Pekerjaan Bebas (Studi Kasus pada KPP Pratama Gambir Tiga)", Simposium Nasional Akuntansi XII, Purwokerto
Yenni. M, Arja. S, 2013, “ Pengaruh Postur Motivasi Terhadap Kepatuhan Wajib Pajak Orang Pribadi", Jurnal Akuntansi dan Keuangan, Vol. 15 No. 2106 - 116

Vanessa T, P Hari, 2009, "Dampak Sunset Policy terhadap Faktor-Faktor yang Mempengaruhi Kemauan Membayar Pajak", Simposium Nasional Perpajakan II

http://beritasore.com/2013/09/23/penerimaanpajak-harusnya-capai-rp-2-000-triliun/

http://bisnis.liputan6.com/read/793346/ penerimaan-pajak-2013-kurang-rp-763triliun-dari-target

http://www.voaindonesia.com/content/bpkpenerimaan-pajak-tidak-capai-targetdalam-4-tahun-terakhir/1683033.html 